\title{
Comparative Assessment of Endoglucanase Activity of Cellulolytic Bacterial Strains on Untreated and Pretreated Natural Cellulosic Wastes
}

\author{
Pinky Prasad ${ }^{1 *}$, Tanuja ${ }^{2}$ and Sheila Bedi ${ }^{1}$ \\ ${ }^{1}$ Department of Botany, Patna Women's College, Patna University, Patna, Bihar, India \\ ${ }^{2}$ Department of Botany, T. P. S. College, Patna, Pataliputra University, Bihar, India
}

*Corresponding author

\section{A B S T R A C T}

\begin{tabular}{l}
\hline Key w o r d s \\
Natural cellulosic \\
wastes, Cellulolytic \\
bacterial strains, \\
Endoglucanase \\
activity, \\
Exoglucanase \\
activity \\
\hline Article Info \\
\hline Accepted: \\
15 April 2020 \\
Available Online: \\
10 May 2020 \\
\hline
\end{tabular}

The aim of the research was isolation of efficient cellulolytic bacterial strains from soil samples and comparative assessment of their cellulolytic potential on untreated and pre-treated cellulosic wastes namely sugarcane bagasse, groundnut shell, corn cob, and vegetable peel so as to determine a suitable substrate pre-treatment for cellulolytic enzyme production. The substrates were pretreated with $0.5 \%$ $\mathrm{NaOH}$ (alkali treatment) and $0.5 \% \mathrm{HCl}$ (acid treatment) and the endoglucanase enzyme production was analyzed on untreated, alkali treated and acid treated substrates by measuring the amount of glucose liberated in IU/ $\mathrm{ml}$ by using the dinitrosalicylic acid assay method. A total of 22 cellulose degrading bacterial strains isolated from 10 soil samples collected randomly from agricultural fields and municipal wastes from different locations in Patna region were screened after primary screening using Congo red and out of these, six of the most promising isolates labeled as PCD1, PCD2, PCD3, PCD4, PCD5 and PCD6 were selected for further investigations on the basis of their enzymatic activity. Amplified and sequenced portion of the 16S rRNA genes of these isolates were BLASTed to determine likely genera and are deposited in the GenBank with their Accession Numbers. PCD1 was identified as Brevibacillus brevis (Accession No. KP851193), PCD2 as Streptomyces matensis (Accession No. KP890933), PCD3 as Ochrobactrum intermedium (Accession No. KP851194), PCD4 as Bacillus subtilis (Accession No. KP851195), PCD5 as Streptomyces griseorubens (Accession No. KP851196) and PCD6 as Achromobacter xylosoxidans (Accession No. KP851197). Comparing the enzyme production by all the selected strains on all the specified untreated and pretreated cellulosic wastes, it was concluded that the maximum amount of enzyme production $(0.2427 \mathrm{IU} / \mathrm{ml})$ was observed on alkali treated sugarcane bagasse by the strain Bacillus subtilis.

\section{Introduction}

Lignocellulosic biomass is the most abundant, inexpensive and renewable carbohydrate continuously added in nature by the process of photosynthesis $(\sim 100$ billion dry tons yr-1) (Zhang and Lynd, 2004). It is comprised of mainly cellulose, a homologous polymer of glucose molecules connected by $\beta-1,4$ linkages, some hemicelluloses, a heterologous polymer of 5- and 6- carbon sugars and least of all lignin a complex aromatic polymer (Maki et al., 2011). A major portion of it is generally not edible and constitutes the agricultural wastes such as leaves, stems, and stalks from sources such as corn fibre, corn 
stover, sugarcane bagasse, rice hulls, woody crops, and forest residues etc.; and municipal wastes such as vegetable peel waste, sawdust, paper pulp etc. (Maki et al., 2009) which accumulate in the environment causing pollution problem. Municipal solid waste is composed of 40-50\% cellulose, 9-12\% hemicelluloses, and 10-15\% lignin on a dry weight basis (Rani and Nand, 2000).

Gautam et al., (2012) reported that Asia generates 4.4 billion tons of solid wastes annually, and municipal solid waste comprises 790 million tons of which about 48 million tons are generated in India.

The bioconversion of lignocellulosic wastes into food, fuel and chemicals is now a subject of intensive research and is considered as the only foreseeable, feasible and sustainable resource beneficial to mankind. The carbon liberated by the biodegradation of cellulose could be widely used to produce sustainable bio-based products and bioenergy to replace depleting fossil fuels (Kiranmayi et al., 2011).

Industrial bioconversion of lignocelluloses is both expensive and time consuming as it requires multiple steps including physical, thermal and/ or chemical pretreatment of the lignocellulosic substrates to break down lignin, decrease crystallinity, increase pore volume and solubilise cellulose and hemicelluloses; saccharification to allow enzymatic hydrolysis of target polysaccharides into monosaccharides; and addition of microorganisms capable of fermentation of the monosaccharides to bioethanol (Maki et al., 2009).

The use of microbial enzymes for consolidated bioprocessing (CBP) of lignocellulosic substrates has led to intensive exploration of natural microbial biodiversity. Several microorganisms including both bacteria and fungi have been found to produce a variety of cellulases for the degradation of cellulose. Cellulases are a consortium of free enzymes comprised of endoglucanases $(\beta-1,4-$ D-glucan-4-glucanohydrolase, EC 3.2.1.4, carboxymethyl cellulase, EC), exoglucanases $(\beta$-1,4-D-glucan-4-glucohydrolase, $\quad$ EC 3.2.1.91, cellobiohydrolase, $\mathrm{CBH})$, and cellobiases ( $\beta$-D-glucoside glucohydrolase, EC 3.2.1.21, $\beta$-1,4-D-glucosidase) are found in many of the 57 glycosyl hydrolase families (Siddiqui et al., 2000). Microbial cellulases are the most economic and available sources, because microorganisms can grow on inexpensive media such agricultural residues and municipal wastes.

The rate and extent of the cellulolytic hydrolysis of lignocellulosic substrates is influenced not only by the effectiveness of the enzymes but also by the chemical, physical and morphological characteristics of the heterogeneous lignocellulosic substrates (Chandra et al., 2007).

A pretreatment step is essential which disrupts the highly ordered cellulose structure and the lignin-carbohydrate complex, remove lignin, and increase the surface area accessible to enzymes, promote the hydrolysis, and increase the rate and extent of hydrolysis of cellulose in various lignocellulosic residues (Fan et al., 1982).

Focusing on the effect of pretreatment of cellulosic substrates on cellulose degradation, the present work was intended to compare the cellulose hydrolysis of untreated, alkali treated and acid treated cellulosic wastes by cellulolytic bacterial strains. Accordingly, the major objectives of the research were isolation of efficient cellulolytic bacterial strains from soil samples and comparative assessment of their cellulolytic potential on untreated and pre-treated cellulosic wastes namely sugarcane bagasse, groundnut shell, corn cob, and vegetable peel. 


\section{Materials and Methods}

\section{Isolation of bacterial strains from soil samples}

Soil samples were collected randomly from a depth of 3-4 inches under aseptic condition from agricultural fields and municipal wastes from 10 different locations in Patna region.

Soil samples were air dried for one week to decrease the population of gram negative bacteria, sieved and plated with fivefold dilution on $\mathrm{CMC}$ agar (Peptone, $5 \mathrm{~g}$; $\mathrm{NaCl}, 5$ g; CMC, 3 g; Agar, 20 g; Distilled water, $1000 \mathrm{ml} ; \mathrm{pH}$ 7.0) plates in duplicates by serial dilution method described by Oskay et al., (2004). All the plates were incubated for $48 \mathrm{~h}$ at $37^{\circ} \mathrm{C}$. The bacterial colonies obtained were purified by repeated sub culturing and maintained on Nutrient Agar slants at $4{ }^{\circ} \mathrm{C}$.

\section{Primary screening of cellulolytic bacterial strains}

The isolated microbes were grown on $\mathrm{CMC}$ agar plates and incubated at $37{ }^{\circ} \mathrm{C}$ for one week. The Petri plates were flooded with $0.1 \%$ Congo red solution for 15 minutes, and then Congo red solution was discarded.

The plates were, then, flooded with $1 \mathrm{~N} \mathrm{HCl}$ solution and allowed to stand for 15 minutes. The strains showing clear zone around the colonies, where the enzyme had utilized the cellulose, were selected for secondary screening.

\section{Secondary screening of cellulolytic bacterial strains}

Potential microbes presenting large clearing zones in Congo red test were screened for their cellulase producing ability using CMC broth. A loopful of the bacterial cultures were inoculated separately in $50 \mathrm{ml}$ of sterilized
CMC broth in $150 \mathrm{ml}$ Erlenmeyer flask and incubated in shaker incubator for four days at $37{ }^{\circ} \mathrm{C}$ for enzymes production. After incubation, the cultures were harvested by centrifugation at $5000 \mathrm{rpm}$ for 10 minutes and the cell free culture supernatants were analysed for enzyme activities.

\section{Measurement of enzyme activity}

\section{Endoglucanase activity}

Endoglucanase (CMCase) activity was measured according to the IUPAC instructions by taking a reaction mixture in a test tube containing $0.5 \mathrm{ml}$ of $1 \% \mathrm{CMC}$ in $0.05 \mathrm{M}$ sodium citrate buffer $(\mathrm{pH}$ 6) with $0.5 \mathrm{ml}$ of enzyme supernatant (Ghose, 1987).

The reaction mixture was incubated at $50{ }^{\circ} \mathrm{C}$ for 30 minutes and to that solution $1 \mathrm{ml}$ of DNS reagent was added and boiled for five minutes in the boiling water bath. The amount of reducing sugar produced was determined by dinitrosalicylic acid (DNS) method (Miller, 1959) by taking absorbance at 540 $\mathrm{nm}$ using spectrophotometer and comparing it with the standard glucose curve.

One unit of CMC-ase activity is defined as the amount of enzyme that released one $\mu$ mole of reducing sugar measured as glucose per minute under the assay conditions.

\section{Exoglucanase activity}

Exoglucanase activity or Filter paper activity (FPase) in the culture filtrate was determined according to the IUPAC instructions by taking Whatman number one filter paper strip $(1 \times 6 \mathrm{~cm}$ or $50 \mathrm{mg})$ immersed in $1 \mathrm{ml}$ of $0.05 \mathrm{M}$ sodium citrate buffer of $\mathrm{pH} 6$ and incubating at $50{ }^{\circ} \mathrm{C}$ for one hour. The reducing sugar released was estimated by dinitrosalicylic acid (DNS) method as described earlier. 


\section{Lignocellulosic sources}

The lignocellulosic substrates used for the present work included sugarcane bagasse, groundnut shell, corn cob, and vegetable peels. One $\mathrm{kg}$ of each of these cellulosic substrates were dipped in five litre of distilled water to remove any soluble sugars present in them and then dried in hot air oven at $80{ }^{\circ} \mathrm{C}$ for 36 hours. The substrates were then grounded and sieved through 100 micrometer mesh size and kept at room temperature. These untreated substrates were used as sources of cellulose for determining the enzyme production by the isolated cellulolytic bacterial strains.

\section{Pretreatment of cellulosic substrates}

The cellulosic substrates were pretreated with alkali and acid. $100 \mathrm{~g}$ of each of the dried and powdered substrates was treated separately for 24 hours with $500 \mathrm{ml}$ of each of $\mathrm{NaOH}$ and $\mathrm{HCl}$ and then repeatedly washed with distilled water to obtain a neutral $\mathrm{pH}$. Then the substrates were dried overnight at $60{ }^{\circ} \mathrm{C}$ and used as sources of cellulose to compare the enzyme production by the isolated cellulolytic bacterial strains.

\section{Enzyme production medium}

Stainer's basal medium $\left(\left(\mathrm{NH}_{4}\right)_{2} \mathrm{SO}_{4} 1 \mathrm{~g}\right.$; K2HPO4 $1 \mathrm{~g} ; \mathrm{MgSO}_{4} 0.2 \mathrm{~g} ; \mathrm{CaCl}_{2} 0.1 \mathrm{~g}$; $\mathrm{FeCl}_{3} 0.02 \mathrm{~g}$; Distilled water, $1000 \mathrm{ml}$; pH7.5) mixed separately with specified cellulosic substrates $(10 \mathrm{~g} / \mathrm{l})$ was used for cellulase production.

\section{Cellulase production}

Ten $\mathrm{ml}$ of Stainer's basal medium was dispensed in 18 tubes each, autoclaved and inoculated with the six selected bacterial strains in triplicates. The tubes were incubated at $37{ }^{\circ} \mathrm{C}$ for four days for cellulase production. The samples were centrifuged at $5000 \mathrm{rpm}$ for 10 minutes. The supernatants obtained were used for the determination of CMCase activities by the method described by Ghose (1987) and for the estimation of reducing sugar released by the method described by Miller (1959).

Molecular characterization and phylogenetic analysis of the selected cellulolytic bacteria

\section{Genomic DNA extraction}

DNA was extracted from 48 hour old culture broth using DNA Isolation Kit (Qiagen) according to the manufacturer instructions and its quality was evaluated on $0.8 \%(\mathrm{w} / \mathrm{v})$ Agarose Gel (HiMedia) in an electrophoresis apparatus (BioRad).

\section{Polymerase chain reaction amplifications}

Fragment of 16S rRNA gene was amplified using PCR kit (Sino-American Biotechnology Co., Beijing) from the above isolated DNA according to the manufacturer instructions. PCR reaction mixture consisted of $1 \mu 180 \mathrm{ng}$ chromosomal DNA, $0.5 \mu \mathrm{l} 200 \mu \mathrm{M}$ of each deoxynucleoside triphosphate (New England Biolabs), $0.8 \mu 180 \mathrm{ng}$ Universal primer $27 \mathrm{f}$ (5'-AGAGTTTGATCMTGGCTCAG-3'), 0.8 $\mu 1 \quad 80$ ng Universal primer 1492r (5'TACGGYTACCTTGTTACGACTT-3'):

Escherichia coli 16S rRNA numbering system (Brosius et. al., 1978), $0.5 \mu 12.5$ Units Taq Polymerase enzyme, $2.5 \mu \mathrm{l}$ X Standard Taq buffer and $18.9 \mu \mathrm{l}$ autoclaved water to make the final volume of $25 \mu$.

PCR cycling parameters included an initial denaturation at $95{ }^{\circ} \mathrm{C}$ for five minutes, followed by 30 cycles of denaturation at 95 ${ }^{\circ} \mathrm{C}$ for one minute, annealing at $55{ }^{\circ} \mathrm{C}$ for one minute and extension at $75{ }^{\circ} \mathrm{C}$ for two minutes and a final extension for ten minutes 
at $75{ }^{\circ} \mathrm{C}$. After completion of PCR, the sample was loaded in a $0.8 \%$ Agarose Gel with a $1 \mathrm{~kb}$ DNA marker supplied by NEB and approximately $1.5 \mathrm{~kb}$ amplified $16 \mathrm{~S}$ rRNA gene fragment was separated by agarose gel electrophoresis, extracted using Qiaquick gel extraction kit (Qiagen) and purified.

\section{Sequencing of PCR products}

Sequencing of the purified PCR products were conducted at Microbial Type Culture Collection (MTCC), Chandigarh and Genomics Services Xcelris Labs Ltd., Ahmedabad.

The obtained 16S rRNA sequences were compared to sequences in the NCBI genebank database with the Basic Alignment Search Tool (BLAST) (Altschul et al., 1990). The $16 \mathrm{~S}$ rRNA gene sequences of the strains are deposited in GenBank and their accession numbers have been obtained.

\section{Phylogenetic analysis}

Phylogenetic trees were constructed using the Neighbor-Joining method in MEGA program version 4.1 (Kumar et al., 2004). The 16S rDNA gene sequences of the type strains of the various genera used in this study were retrieved from the GeneBank database and used for cladistic analysis. These sequences have been chosen as reference sequences.

\section{Results and Discussion}

\section{Isolation and enumeration of cellulolytic bacterial strains}

From all of the soil samples collected, a total of 22 cellulose degrading isolates (Figure 1) were screened after primary screening using Congo red. Out of these, six cellulaseproducing isolates labeled as PCD1, PCD2,
PCD3, PCD4, PCD5 and PCD6 were selected after secondary screening by determining their potentiality for cellulase production.

Endoglucanase activity of the selected isolates ranged between $15.91 \mathrm{IU} / \mathrm{ml}$ and $17.76 \mathrm{IU} / \mathrm{ml}$. Maximum endoglucanase activity was shown by PCD1 (17.76 IU/ml). It was same for the strains PCD2, PCD3, PCD4 and PCD6 and was found to be $16.65 \mathrm{IU} / \mathrm{ml}$. It was least for the strain PCD5 (15.91 IU/ml).

Exoglucanase activity of the selected isolates ranged between $10.36 \mathrm{IU} / \mathrm{ml}$ and $11.10 \mathrm{IU} / \mathrm{ml}$. It was $11.10 \mathrm{IU} / \mathrm{ml}$ for the strains PCD1 and PCD2; $10.73 \mathrm{IU} / \mathrm{ml}$ for the strains PCD3 and PCD4; $10.55 \mathrm{IU} / \mathrm{ml}$ for the strain PCD5; and $10.36 \mathrm{IU} / \mathrm{ml}$ for the strain PCD6. The data are shown in Figure 2.

\section{Estimation of endoglucanase production by the selected bacterial strains on different untreated and pretreated cellulosic wastes}

The production of cellulases using various substrates and nutrients by fungi and bacteria has been reported by many workers (Macris et al., 1989; Krishna, 1999; Lakshmikant and Mathur, 1990; Immanuel et al., 2006; Kiranmayi et al., 2011). However, some workers (Kotchoni et al., 2006; Odeniyi, 2009; Robson and Chambliss, 1984) have reported that the cellulolytic bacteria especially the Bacillus strains are capable of hydrolyzing amorphous carboxymethyl cellulose but there are not sufficient records on Bacillus species possessing ability to degrade the more crystalline cellulosic substrates.

Keeping this in view, the present study was aimed at determining the endoglucanases secreted by the selected bacterial isolates which acts on the amorphous portion of the cellulosic substrate. The natural lignocellulosic wastes are difficult to be 
hydrolysed by cellulolytic enzymes due to presence of recalcitrant lignin and hemicelluloses (Mansfield et al., 1999; Esteghlalian et al., 2001). Besides this, degree of polymerization and cellulose crystallinity (Chang and Holtzapple, 2000); accessible surface area (Taherzadeh and Karimi, 2008) and pore size of the substrate in relation to the size of the enzymes (Chandra et al., 2007) are other limiting factors in the enzymatic hydrolysis of lignocellulosic biomass. Thus, the lignocellulosic wastes were chemically treated separately with alkali and acid for efficient enzymatic conversion; and a comparative assessment of endoglucanase activity was done.

The endoglucanase production using sugarcane bagasse by PCD1 in untreated condition was $0.0444 \mathrm{IU} / \mathrm{ml}$, in acid treated $0.0499 \mathrm{IU} / \mathrm{ml}$ and in alkali treated 0.0444 $\mathrm{IU} / \mathrm{ml}$. The same by PCD2 was $0.0170 \mathrm{IU} / \mathrm{ml}$ (untreated), $0.0189 \mathrm{IU} / \mathrm{ml}$ (acid treated) and $0.0189 \mathrm{IU} / \mathrm{ml}$ (alkali treated). For PCD3 the value was $0.0163 \mathrm{IU} / \mathrm{ml}$ (untreated), 0.0244 $\mathrm{IU} / \mathrm{ml}$ (acid treated), $0.0192 \mathrm{IU} / \mathrm{ml}$ (alkali treated); for PCD4 it was $0.0481 \mathrm{IU} / \mathrm{ml}$ (untreated), $0.0858 \mathrm{IU} / \mathrm{ml}$ (acid treated), $0.2427 \mathrm{IU} / \mathrm{ml}$ (alkali treated); for PCD5 it was $0.0407 \mathrm{IU} / \mathrm{ml}$ (untreated), $0.0437 \mathrm{IU} / \mathrm{ml}$ (acid treated), $0.0647 \mathrm{IU} / \mathrm{ml}$ (alkali treated); for PCD6 it was $0.0181 \mathrm{IU} / \mathrm{ml}$ (untreated), 0.0233 $\mathrm{IU} / \mathrm{ml}$ (acid treated), $0.0215 \mathrm{IU} / \mathrm{ml}$ (alkali treated). The data has been presented in Figure 3.

The endoglucanase production using corn cob by PCD1 in untreated condition was 0.0573 $\mathrm{IU} / \mathrm{ml}$, in acid treated $0.0651 \mathrm{IU} / \mathrm{ml}$ and in alkali treated $0.0740 \mathrm{IU} / \mathrm{ml}$. The same by PCD2 was $0.0185 \mathrm{IU} / \mathrm{ml}$ (untreated), 0.0196 $\mathrm{IU} / \mathrm{ml}$ (acid treated) and $0.0189 \mathrm{IU} / \mathrm{ml}$ (alkali treated). For PCD3 the value was 0.0160 $\mathrm{IU} / \mathrm{ml}$ (untreated), $0.0250 \mathrm{IU} / \mathrm{ml}$ (acid treated), $0.1920 \mathrm{IU} / \mathrm{ml}$ (alkali treated); for PCD4 it was $0.1232 \mathrm{IU} / \mathrm{ml}$ (untreated), 0.1591
$\mathrm{IU} / \mathrm{ml}$ (acid treated), $0.1776 \mathrm{IU} / \mathrm{ml}$ (alkali treated); for PCD5 it was $0.0385 \mathrm{IU} / \mathrm{ml}$ (untreated), $0.0444 \mathrm{IU} / \mathrm{ml}$ (acid treated), $0.0795 \mathrm{IU} / \mathrm{ml}$ (alkali treated); for PCD6 it was $0.0192 \mathrm{IU} / \mathrm{ml}$ (untreated), $0.0216 \mathrm{IU} / \mathrm{ml}$ (acid treated), $0.0201 \mathrm{IU} / \mathrm{ml}$ (alkali treated). The data has been presented in Figure 4 .

The endoglucanase production using groundnut shell by PCD1 in untreated condition was $0.0573 \mathrm{IU} / \mathrm{ml}$, in acid treated $0.0851 \mathrm{IU} / \mathrm{ml}$ and in alkali treated 0.0573 $\mathrm{IU} / \mathrm{ml}$. The same by PCD2 was $0.0181 \mathrm{IU} / \mathrm{ml}$ (untreated), $0.0185 \mathrm{IU} / \mathrm{ml}$ (acid treated) and $0.0233 \mathrm{IU} / \mathrm{ml}$ (alkali treated). For PCD3 the value was $0.0160 \mathrm{IU} / \mathrm{ml}$ (untreated), 0.0259 $\mathrm{IU} / \mathrm{ml}$ (acid treated), $0.0174 \mathrm{IU} / \mathrm{ml}$ (alkali treated); for PCD4 it was $0.0388 \mathrm{IU} / \mathrm{ml}$ (untreated), $0.0414 \mathrm{IU} / \mathrm{ml}$ (acid treated), $0.0507 \mathrm{IU} / \mathrm{ml}$ (alkali treated); for PCD5 it was $0.0370 \mathrm{IU} / \mathrm{ml}$ (untreated), $0.0425 \mathrm{IU} / \mathrm{ml}$ (acid treated), $0.0425 \mathrm{IU} / \mathrm{ml}$ (alkali treated); for PCD6 it was $0.0174 \mathrm{IU} / \mathrm{ml}$ (untreated), 0.0244 $\mathrm{IU} / \mathrm{ml}$ (acid treated), $0.0174 \mathrm{IU} / \mathrm{ml}$ (alkali treated). The data has been presented in Figure 5.

The endoglucanase production using vegetable peel by PCD1 in untreated condition was $0.0518 \mathrm{IU} / \mathrm{ml}$, in acid treated $0.0536 \mathrm{IU} / \mathrm{ml}$ and in alkali treated 0.0832 $\mathrm{IU} / \mathrm{ml}$. The same by PCD2 was $0.0174 \mathrm{IU} / \mathrm{ml}$ (untreated), $0.0189 \mathrm{IU} / \mathrm{ml}$ (acid treated) and $0.0181 \mathrm{IU} / \mathrm{ml}$ (alkali treated).

For PCD3 the value was $0.0166 \mathrm{IU} / \mathrm{ml}$ (untreated), $0.0215 \mathrm{IU} / \mathrm{ml}$ (acid treated), $0.0185 \mathrm{IU} / \mathrm{ml}$ (alkali treated); for PCD4 it was $0.0451 \mathrm{IU} / \mathrm{ml}$ (untreated), $0.0466 \mathrm{IU} / \mathrm{ml}$ (acid treated), $0.0784 \mathrm{IU} / \mathrm{ml}$ (alkali treated); for PCD5 it was $0.0444 \mathrm{IU} / \mathrm{ml}$ (untreated), 0.0555 $\mathrm{IU} / \mathrm{ml}$ (acid treated), $0.0499 \mathrm{IU} / \mathrm{ml}$ (alkali treated); for PCD6 it was $0.0196 \mathrm{IU} / \mathrm{ml}$ (untreated), $0.0207 \mathrm{IU} / \mathrm{ml}$ (acid treated), $0.1960 \mathrm{IU} / \mathrm{ml}$ (alkali treated). The data has been presented in Figure 6 . 
It was found that in all cases, the endoglucanase activity was more in the pretreated cellulosic wastes as compared to the untreated ones indicating the effectiveness of pretreatment of substrates in achieving acceptable enzymatic digestibility. Pretreatment alters or removes the physical and chemical impediments that inhibit the accessibility of the enzyme to the substrates. In the present study, the alkali treatment of cellulosic wastes was found superior compared to acid treatment for enzymatic hydrolysis.

Alkali pretreatment method which is more effective on agricultural residues than on wood materials (Kumar and Wyman,2009) causes swelling, increasing the internal surface of cellulose and decreasing the degree of polymerization and crystallinity, which provokes lignin disruption (Playne, 1984). However, acid treatment of groundnut shell proved to be better substrate for enzyme production by the strains PCD1, PCD3 and PCD6. But acid treatment of substrate generates toxic degradation products (Saritha et al., 2012), hence, should be avoided.

The degradation of sugarcane bagasse ranged between $0.0189 \mathrm{IU} / \mathrm{ml}$ and $0.2427 \mathrm{IU} / \mathrm{ml}$ by the selected isolates in four days; that of corn cob between $0.0189 \mathrm{IU} / \mathrm{ml}$ and $0.0740 \mathrm{IU} / \mathrm{ml}$; that of groundnut shells between 0.0174 $\mathrm{IU} / \mathrm{ml}$ and $0.0 .573 \mathrm{IU} / \mathrm{ml}$; and that of vegetable peel between $0.0181 \mathrm{IU} / \mathrm{ml}$ and $0.1960 \mathrm{IU} / \mathrm{ml}$.

Regarding the enzymatic efficiency of the isolates, it was observed that PCD4 was able to degrade all of the substrates used in the present study considerably as compared to the other isolates. It was the most efficient strain in degrading sugarcane bagasse; second to PCD3 in degrading corn cob and PCD1 in degrading groundnut shell, respectively. In degrading vegetable peel its position was after
PCD6 and PCD1 as shown in Table 1. Comparing the enzyme production by all the selected strains on all the specified untreated and pretreated cellulosic wastes, it was concluded that the maximum amount of enzyme production was observed on alkali treated sugarcane bagasse by the strain PCD4 in four days.

\section{Identification of the selected cellulolytic bacterial strains}

The purified and amplified PCR products of strains PCD1, PCD2 and PCD5 were sequenced at MTCC, Chandigarh; and that of the strains PCD3, PCD4 and PCD6 were sequenced at Genomics Services Xcelris Labs Ltd., Ahmedabad. The results obtained from the sequencing of these isolates were inputted to the nucleotide blast feature of the NCBI database to obtain possible identities based on homology (Table 2).

The 16S rRNA sequences of strains determined in this study have been deposited in the GenBank database with their Accession Numbers. PCD1 showed 99\% homology with Brevibacillus brevis and is deposited in the Genbank with Accession No. KP851193. PCD2, PCD3, PCD4 and PCD5 showed $100 \%$ homology with Streptomyces matensis (Accession No. KP890933), Ochrobactrum intermedium (Accession No. KP851194), Bacillus subtilis (Accession No. KP851195) and Streptomyces griseorubens (Accession No. KP851196), respectively. PCD6 showed 99\% homology with Achromobacter xylosoxidans and is deposited in the Genbank with Accession No. KP851197.

\section{Phylogenetic analysis}

The evolutionary history was inferred using the Neighbor-Joining method. Phylogenetic trees of all of the selected isolates are presented from Figure 7-12. 
Table.1 Enzymatic efficiency of isolates in degrading substrates in four days

\begin{tabular}{|l|c|c|c|l|}
\hline S.N. & Substrate & \multicolumn{3}{|c|}{ Three most efficient cellulolytic isolates in ascending } \\
order
\end{tabular}

Table.2 BLAST search results for the sequenced cellulase producing isolates

\begin{tabular}{|l|l|l|l|}
\hline S.N. & Isolate & Homology (\%) & Organism \\
\hline $\mathbf{1}$ & PCD1 & 99 & Brevibacillus brevis \\
\hline $\mathbf{2}$ & PCD2 & 100 & Streptomyces matensis \\
\hline $\mathbf{3}$ & PCD3 & 100 & Ochrobactrum intermedium \\
\hline $\mathbf{4}$ & PCD4 & 100 & Bacillus subtilis \\
\hline $\mathbf{5}$ & PCD5 & 100 & Streptomyces griseorubens \\
\hline $\mathbf{6}$ & PCD6 & 99 & Achromobacter xylosoxidans \\
\hline
\end{tabular}

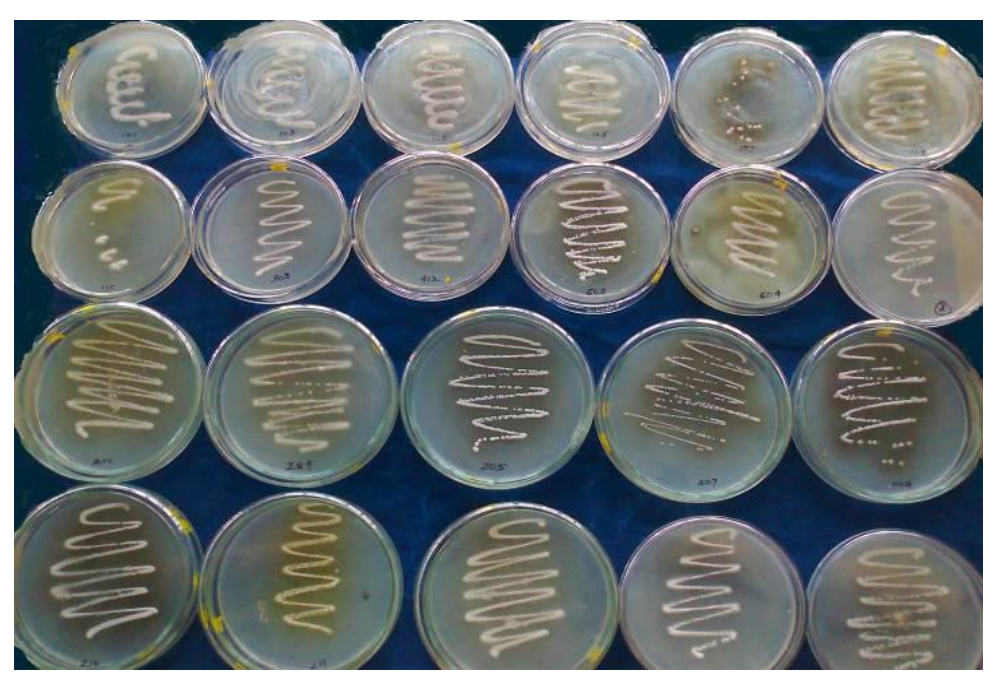

Fig.1 Cellulose degrading bacterial strains screened after primary screening 


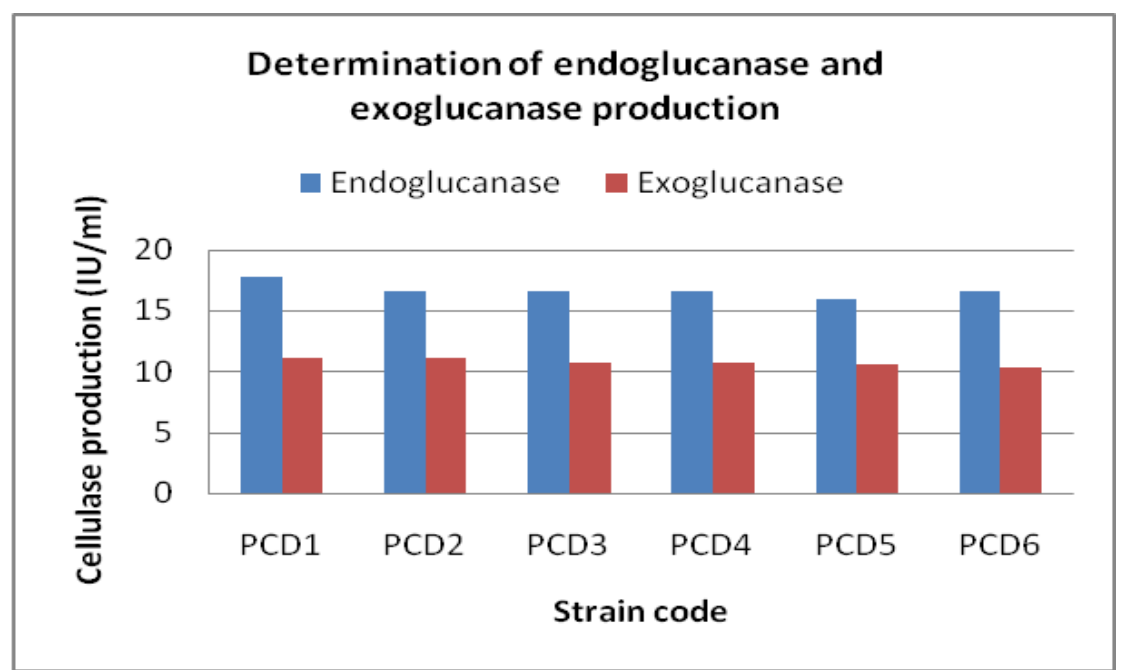

Fig.2 Determination of cellulase production by the selected cellulose degrading bacterial strains

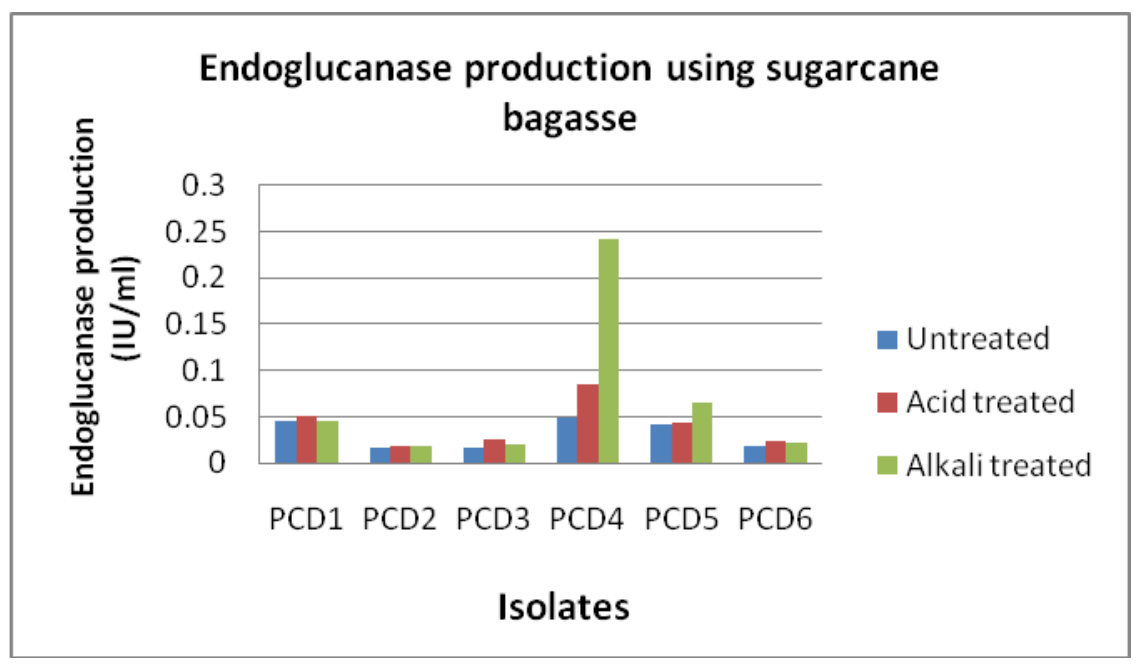

Fig.3 Endoglucanase production by the isolates using sugarcane bagasse as substrate

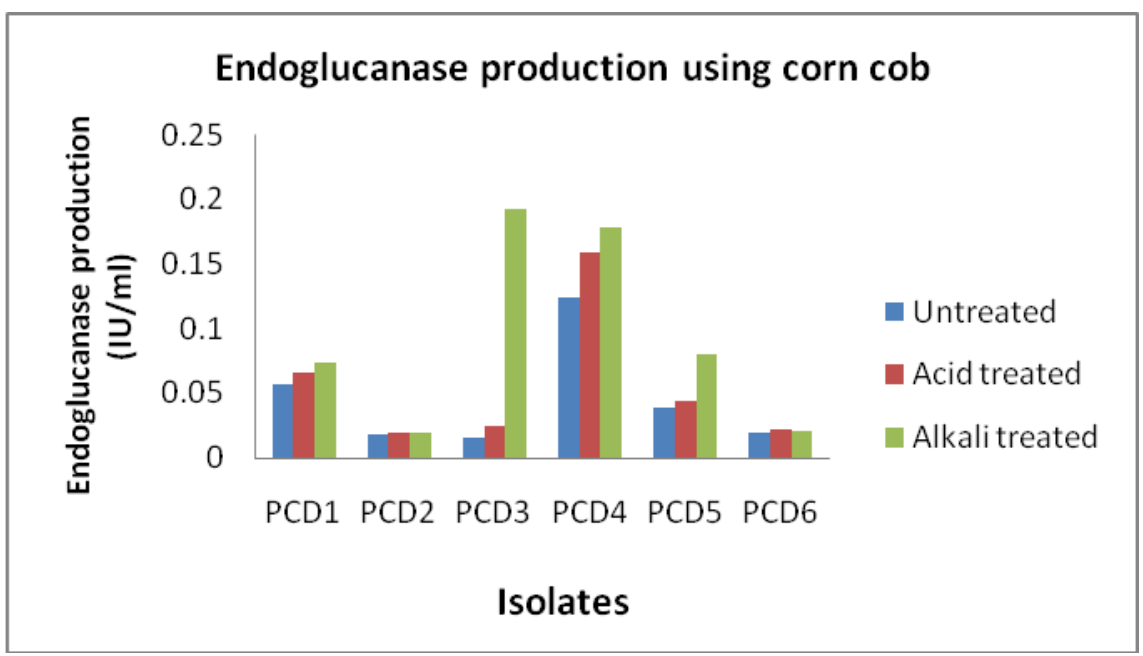

Fig.4 Endoglucanase production by the isolates using corn cob as substrate 


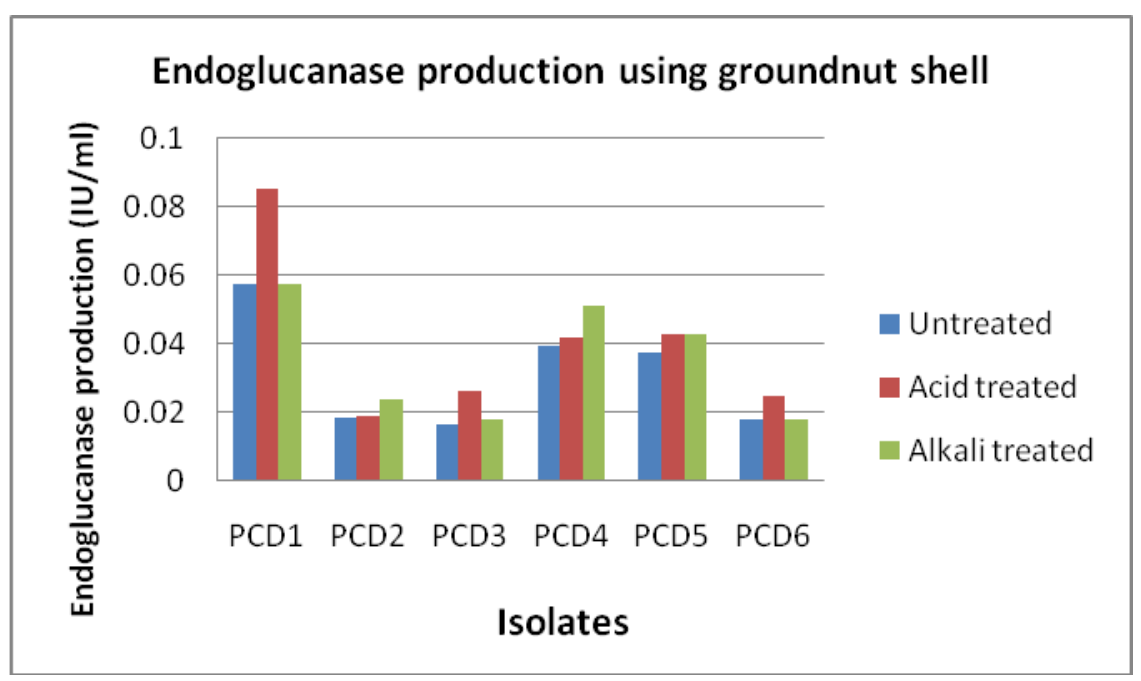

Fig.5 Endoglucanase production by the isolates using groundnut shell as substrate

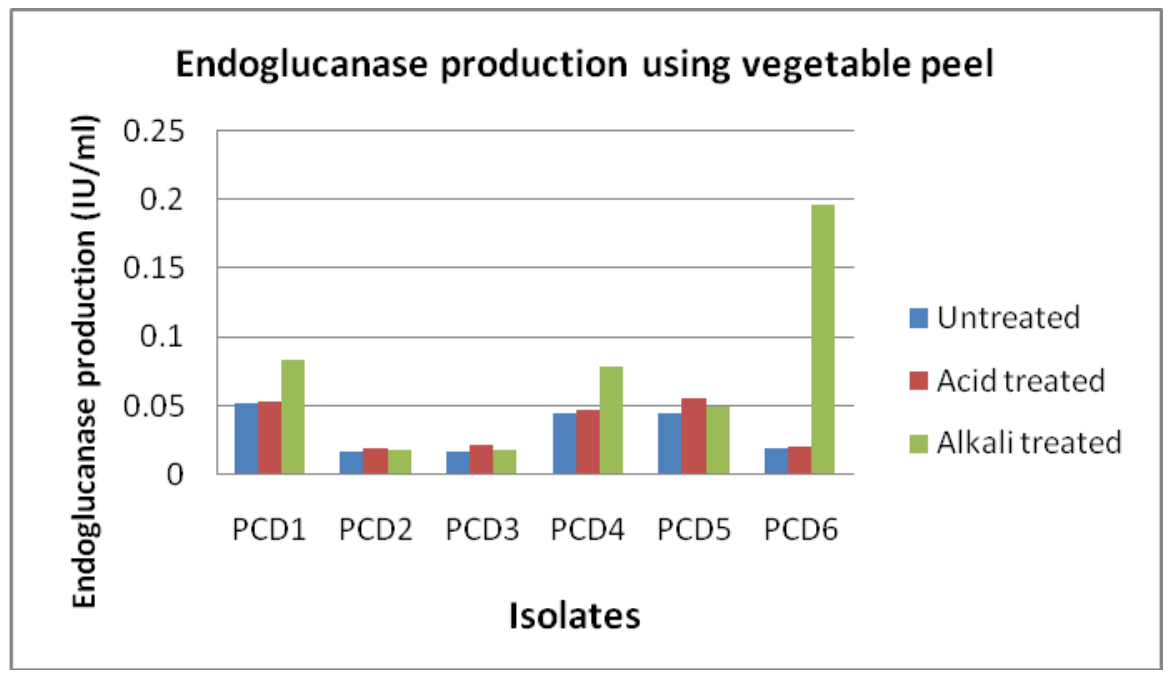

Fig.6 Endoglucanase production by the isolates using vegetable peel as substrate

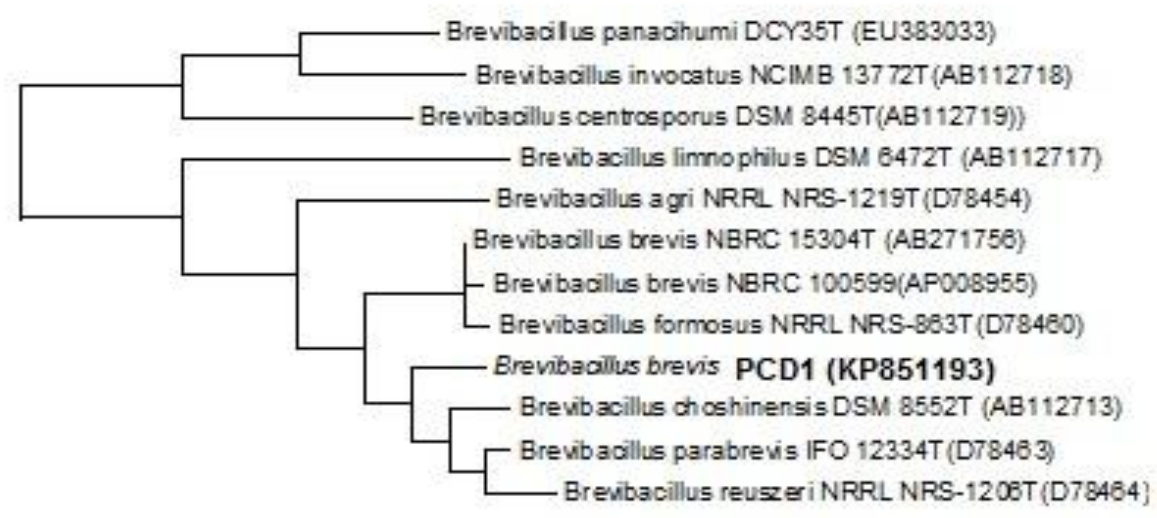

Fig.7 Phylogenetic Neighbor-Joining tree of the isolate PCD1 


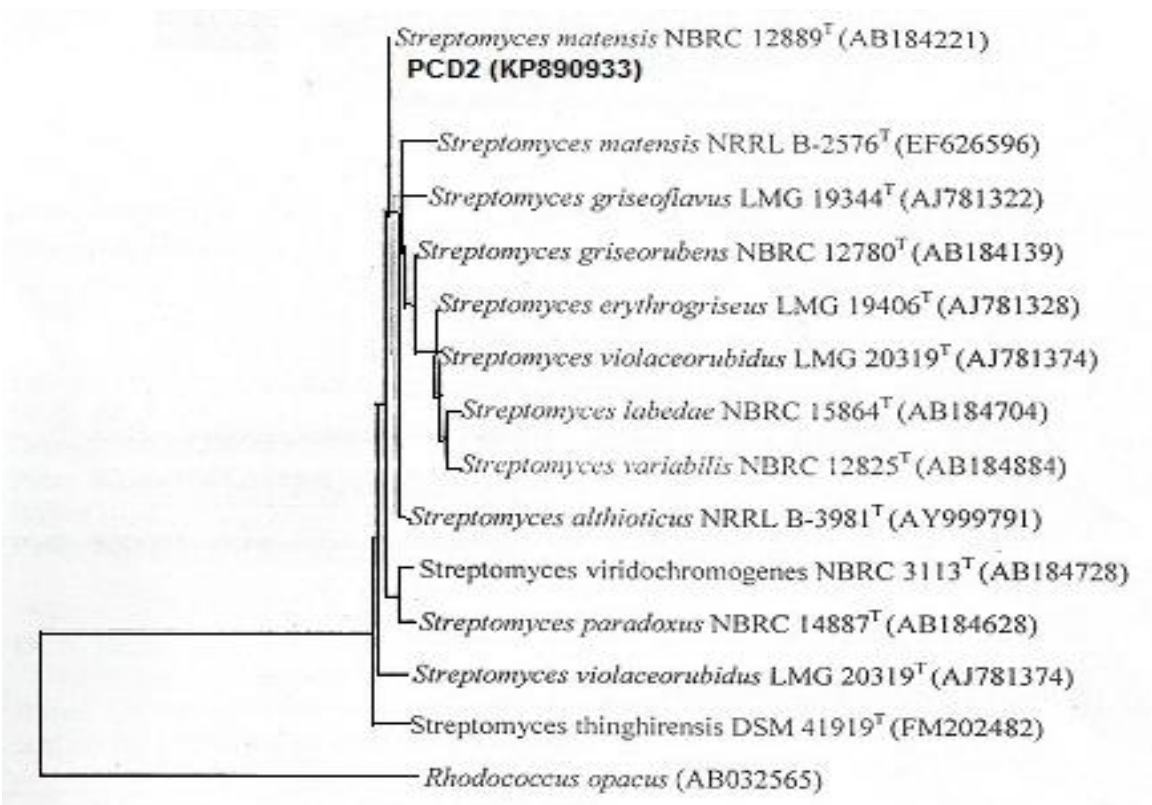

Fig.8 Phylogenetic Neighbor-Joining tree of the isolate PCD2

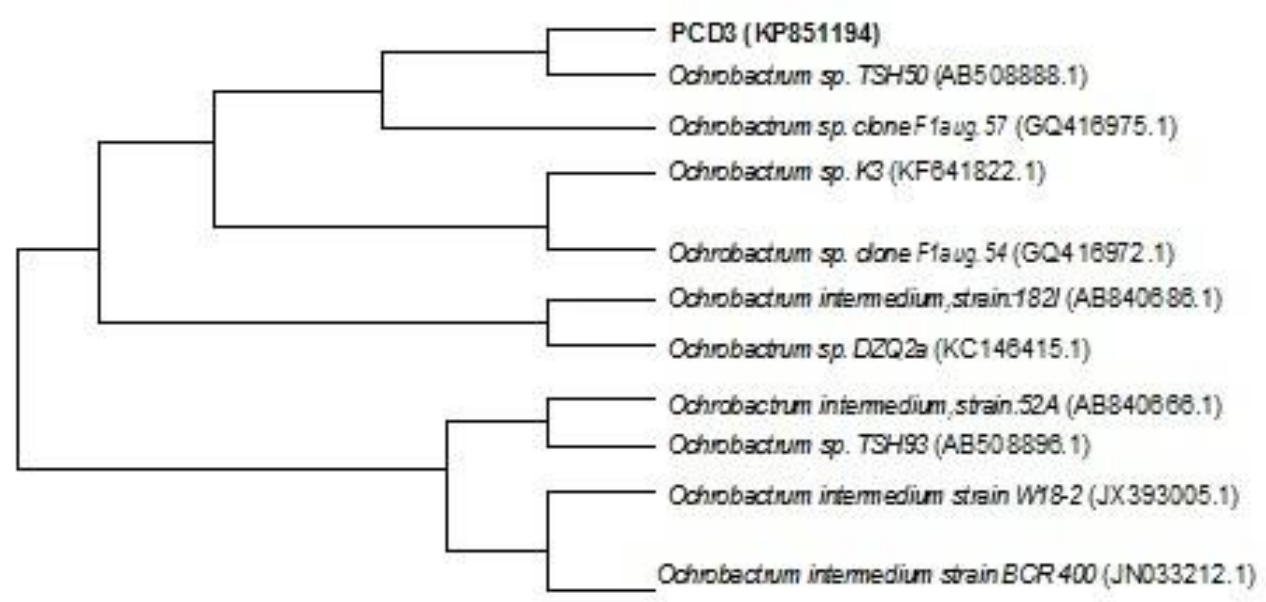

Fig.9 Phylogenetic Neighbor-Joining tree of the isolate PCD3

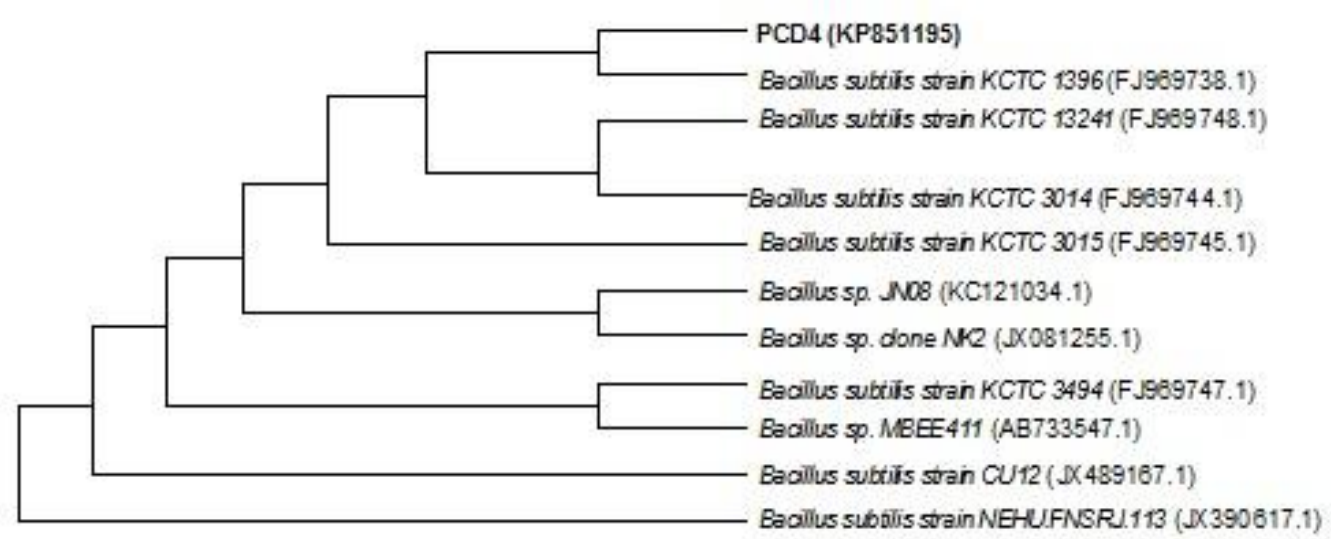

Fig.10 Phylogenetic Neighbor-Joining tree of the isolate PCD4 


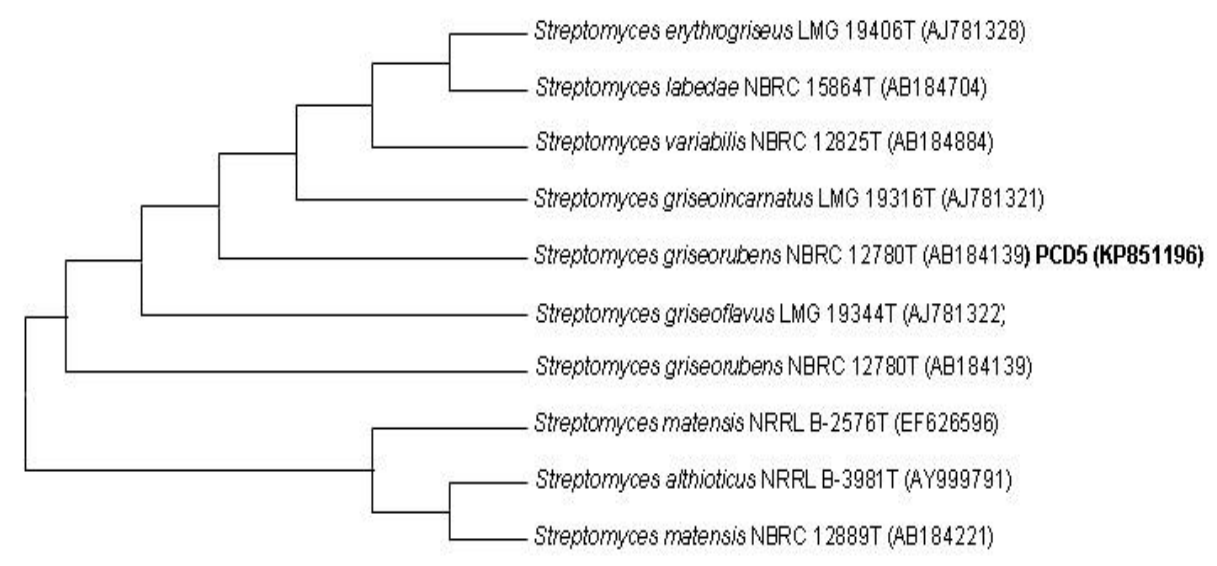

Fig.11 Phylogenetic Neighbor-Joining tree of the isolate PCD5

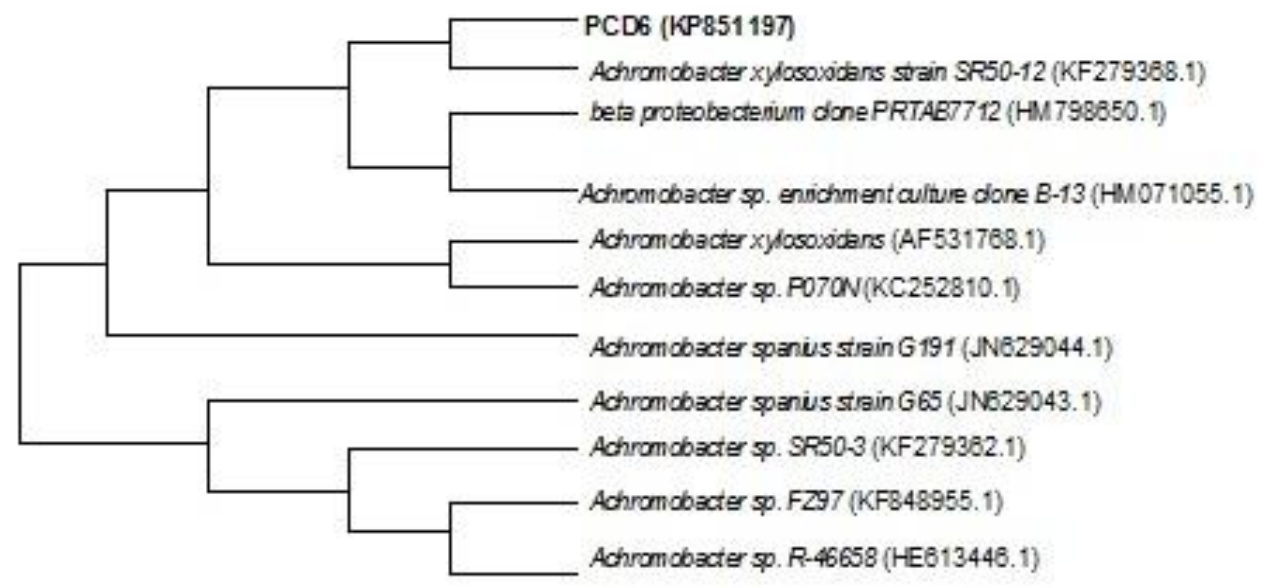

Fig.12 Phylogenetic Neighbor-Joining tree of the isolate PCD6

Based on the reported results, it may be concluded that alkali treated sugar cane bagasse can be a potential substrate for production of cellulase using the bacterial strain Bacillus subtilis. The aim of this work is to produce cellulase from natural cellulosic wastes and reduce the pollution.

\section{Acknowledgements}

The authors gratefully acknowledge DST, Ministry of Science and Technology, Govt. of India for financial support under WOS-A scheme and Sister Marie Jessie, Principal, Patna Women's College for providing necessary infrastructural facilities.

\section{References}

Altschul, S. F., Jenkins, A., Kristiansen, B. E. and FrØholm, C. O. (1990). Basic local alignment search tool . Journal of Molecular Biology, 215, 403-410.

Brosius, J., Palmer M. L., Kennedy P. J. and Noller H. F. (1978). Complete nucleotide sequence of a $16 \mathrm{~S}$ ribosomal RNA gene from Escherichia coli. Proceedings of the National Academy of Sciences of the United States of America 75(10), 4801-4805.

Chandra, R. P., Bura, R., Mabee, W. E., Berlin, A., Pan, X. and Saddler, J. N. (2007). Substrate pretreatment: the key 
to effective enzymatic hydrolysis of lignocellulosics? Advances in Biochemical Engineering/ Biotechnology, 108, 67-93.

Chang, V. S. and Holtzapple, M. (2000). Fundamental factors affecting biomass reactivity. Applied Biochemistry and Biotechnology, 84, 5-37.

Esteghlalian, A. R., Srivastava, V., Gilkes, N., Gregg, D. J. and Saddler, J. N. (2001). An overview of factors influencing the enzymatic hydrolysis of lignocellulosic feedstocks. In: Himmel, M.E., Baker, W. and Saddler, J.N. (eds.), Glycosyl hydrolases for biomass conversion, Washington, DC, ACS, pp. $100-111$.

Fan, L. T., Young-Hyun, L. and Gharpuray, M. M. (1982). The nature of lignocellulosics and their pretreatments for enzymatic hydrolysis. Advances in Biochemical Engineering, 23, 157-187.

Gautam, S. P., Bundela, P. S., Pandey, A. K. Jamaluddin, Awasthi, M. K. and Sarsaiya, S. (2012). Diversity of Cellulolytic Microbes and the Biodegradation of Municipal Solid Waste by a Potential Strain. International Journal of Microbiology, Vol 2012.

Ghose, T. K. (1987). Measurement of cellulase activities. Pure and Applied Chemistry, 59, 257-68.

Immanuel, G., Dhanusa, R., Prema, P. and Palavesam, A. (2006). Effect of different growth parameters on endoglucanase enzyme activity by bacteria isolated from coir retting effluents of estuarine environment. International Journal of Environmental Science and Technology, 3, 25-34.

Kiranmayi, M. U., Poda, S., Vijayalakshmi, M. and Krishna, P. V. (2011). Studies on influence of natural biowastes on cellulase production by Aspergillus niger. Journal of Environmental
Biology, 32, 695-699.

Kotchoni, S. O., Gachomo, E. W., Omafuvbe, B. O. and Shonukan, O. O. (2006). Purification and Biochemical Characterization of Carboxymethyl Cellulase (CMCase) from a Catabolite Repression Insensitive Mutant of Bacillus pumilus. International Journal of Agriculture and Biology, 8(2), 286292.

Krishna, C. (1999). Production of bacterial cellulases by solid state bioprocessing banana wastes. Bioresource Technology, 69, 231-239.

Kumar, R. and Wyman, C. E. (2009). Effects of cellulase and xylanase enzymes on the deconstruction of solids from pretreatment of poplar by leading technologies. Biotechnology Progress, 25,302-314.

Kumar, S., Tamura, K. and Nei, M. (2004). MEGA3: Integrated software for molecular evolutionary genetics analysis and sequence alignment. Briefings in Bioinformatics, 5, 150163.

Lakshmikant, K. and Mathur, S. N. (1990). Cellulolytic activities of Chaetomium globosum on different cellulosic substrates. World Journal of Microbiology and Biotechnology, 11, 23-26.

Macris, B. J., Kekos, D. and Evrangelidou, X. (1989). A simple and inexpensive method for cellulase and b-glusidase production by Aspergillus niger. Applied Microbiology and Biotechnology, 31, 150-151.

Maki M. L., Broere M., Leung, K. T. and Qin W. (2011). Characterization of some efficient cellulase producing bacteria isolated from paper mill sludge and organic fertilizers. International Journal of Biochemistry and Molecular Biology, 2(2), 146-154.

Maki, M., Leung, K. T. and Qin, W. (2009). 
The prospects of cellulase-producing bacteria for the bioconversion of lignocellulosic biomass. International Journal of Biological Sciences, 5(5), 500-516.

Mansfield, S. D., Mooney, C. and Saddler, J. N. (1999). Substrate and enzyme characteristics that limit cellulose hydrolysis. Biotechnology Progress, 15, 804-816.

Miller, G. L. (1959). Use of dinitrosalicylic acid reagent for determination of Reducing sugar. Analytical Chemistry, $31,426-428$.

Odeniyi, O. A., Onilude, A. A. and Ayodele, M. A. (2009). Production characteristics and properties of cellulase/ polygalacturonase by a Bacillus coagulans strain from a fermenting palm-fruit industrial residue. African Journal of Microbiology Research, 3(8), 407-417.

Oskay, M., Same, A. and Azeri, C. (2004). Antibacterial activity of some actinomycetes isolated from farming soils of Turkey. Africal Journal of Biotechnology, 3, 441-446.

Playne, M. J. (1984). Increased digestibility of bagasse by pretreatment with alkalis and steam explosion. Biotechnology and Bioengineering, 26, 426-433.

Rani, D. S. and Nand, K. (2000). Production of thermostable cellulase-free xylanase by Clostridium

absonumCFR-702.

Process Biochemistry, 36(4), 355-362.

Robson, L. M. and Chambliss, G. H. (1984). Characterization of the Cellulolytic Activity of a Bacillus Isolate. Applied and Environmental Microbiology, 47(5), 1039-1046.

Saritha, M., Arora, A. and Lata. (2012). Biological Pretreatment of Lignocellulosic Substrates for Enhanced Delignification and Enzymatic Digestibility. Indian Journal of Microbiology, 52(2), 122-130.

Siddiqui, K. S., Saqio, A. A. N., Rashid, M. H. and Rajoka, M. I. (2000). Carboxyl group modification significantly altered the kinetic properties of purified carboxymethyl cellulase from Aspergillus niger. Enzyme and Microbial Technology, 27, 467-474.

Taherzadeh, J. M. and Karimi, K. (2008). Pretreatment of lignocellulosic wastes to improve ethanol and biogas production: a review. International Journal of Molecular Sciences, 9, 16211651.

Zhang, Y. H. P. and Lynd, L. R. (2004). Toward an aggregated understanding of enzymatic hydrolysis of cellulose: Noncomplexed cellulase systems. Biotechnology and Bioengineering, 88, 797-824.

\section{How to cite this article:}

Pinky Prasad, Tanuja and Sheila Bedi. 2020. Comparative Assessment of Endoglucanase Activity of Cellulolytic Bacterial Strains on Untreated and Pretreated Natural Cellulosic Wastes. Int.J.Curr.Microbiol.App.Sci. 9(05): 1974-1987. doi: https://doi.org/10.20546/ijcmas.2020.905.224 